Research Article

\title{
GENDER AND ETHNICITY DIMENSIONS IN RELATION TO ACCESS TO AND CONTROL OVER HOUSEHOLD RESOURCES IN NEPAL
}

\author{
D. Devkota \\ Institute of Agriculture and Animal Sciences (IAAS), Rampur, Chitwan, Nepal
}

\begin{abstract}
The study examined gender roles in access to, and control over, household resources in three culturally distinct ethnic groups of rural Nepal. Gender analysis using Harvard Analytical Framework and face-toface interviews with one male and one female member from each of the 123 households were conducted. The results indicated that men dominated in all aspects of household resources in all the ethnic groups (Brahmin/Chhetri, Gurung, and Tharu). The Gurung women fared relatively better compared to women in other two ethnic groups. This could be due to prolonged absence of male household members among Gurung households. The responses from female household members were mostly in conformity with those obtained from male members. Furthermore, findings from the gender analysis were consistent with household survey results conducted by 1998. The validation of findings using both methods suggests that the results are reliable and can be used for policy formulation for rural development.
\end{abstract}

Key words: Gender, household resources, ethnicity, farming

\section{INTRODUCTION}

Traditionally, the primary responsibility of men has been to generate sufficient income to fulfill the household requirements including food, shelter, education, healthcare and other necessities (Thomas-Slater and Rocheleau, 1995). Men tend to be more involved in public affairs such as participation in social gatherings, attending meetings and discussions and religious ceremonies than women. Meanwhile, women are considered to be housewives and mothers devoted to domestic work (Moser, 1993; Okojie, 1996; Devkota, 1999). However, in practice, women play an active role in every aspect of family life (Subedi, 1997; Anonymous, 2002). They have primary responsibility for meeting the family's basic needs for food, water and fuel wood; particularly in rural areas women are further engaged in mundane household chores (Barrett and Brown, 1993). Women's multiple roles in the family are not fully recognized and thus their contributions are undervalued (Acharya, 1994). This is due to lack of official account reporting of family workers engaged in both subsistence and market oriented farming (Jazairy et al., 1992).

In South Asia, farming systems are of traditional nature in which women are involved in labour intensive tasks like transplanting, weeding, harvesting and livestock raising. Men, on the other hand, take responsibility of activities requiring heavy physical labour such as land preparation using draught power, irrigation, transport of farm produce and marketing (Wickramasinghe, 1993). This does not necessarily mean that men spend more hours than women. The labour use patterns in farming tend to be similar across regions, but gender involvement varies across regions and by activity and ethnicity (Acharya, 1993; Devkota, 1999).

Gender roles often tend to be associated with access to, and control over, household resources. Access to, and control over, household resources is widely accepted indicators of gender empowerment and depend on multitude of factors including social norms, taboos, gender dominance and cultural systems. In developing countries women tend to be at disadvantage in access to, and control over, resources. This may stem from restricted ownership of resources (including land), limited or no access to technical know-how or inputs, production of low-value commodities; all contributing to less than satisfactory return from farming (Buvinic and Mehra, 1990). Policy-makers assume that trickle-down theory works and knowledge imparted to males eventually trickles down to females. Unfortunately, this does not happen to the desired extent due to various barriers and women are left with incomplete information (Prah, 1997). An understanding of access to, and control over household resources by men and women in households, is critical in formulating rural development strategies and policies. This ought to be examined by ethnicity in multi-ethnic societies so that policy instrument is sensitive to local needs. This study thus aimed to examine the concern of gendering on access to, and control over, household resources in the context of rural Nepal. 


\section{Gender roles in Nepal}

An ethnic group is defined as a "collectivity" within a larger society having real or so-called common ancestry, memories of a shared historical past, and a cultural focus on one or more symbolic elements defined as the characteristics of their ancestors (Hutchinson and Smith, 1996). Therefore, any group of people, which is dissimilar from other people in terms of cultural criteria, such as language or dialect, distinctive dress or diet or customs, religion or race, can constitute an ethnic group (Paul, 1996). Nepal's population is multi-ethnic with a range of cultural and religious backgrounds. Substantial differences in gender roles have been observed, but the degree of disparity in gender roles varies by geographical location, ethnicity and culture. Nepalese women, in general have less access to income, wealth, employment and education than men, and have fewer legal rights, especially in relation to property and family matters (Shrestha, 1994). A number of studies have documented about gender inequalities in the Nepalese society (Acharya, 1994; Bajracharya, 1994; Subedi, 1997; Anonymous, 2002). For example, more than $77 \%$ of women in rural Nepal are illiterate compared with about $50 \%$ of men (CBS, 1997). Women have very little control over crop land, livestock or daily wages (Acharya, 1993; Bajracharya, 1994). Rural women have less freedom than men to make choices over the use of their time. This meant limited opportunities for their personal development, especially involvement in activities organized for training or higher education. It also reinforces their mental state of dependence on males for survival, which tends to suppress them in daily life (Bajracharya, 1994).

\section{METHODOLOGY}

The fieldwork of this study was carried out between April and June 1998 in three Village Development Committees (VDCs), namely Bhandara, Phulbari and Shivanagar of Chitwan district of Central Nepal. The study examined gender roles on access to, and control over, household resources on three distinct ethnic groups (Brabmin/Chbetri, Gurung and Tharu) of the district. These ethnic groups were selected on the basis of their similar occupations, but different settlement history. The Gurung ethnic group was included in the study because of the compatibility of their occupations with those of the Brabmin/Chbetris and Tharus. The process of study was accomplished in two-steps. The first was gender analysis using Harvard Analytical Framework (Overholt et al., 1991). This was carried separately with male and female groups in each of the selected VDCs and ethnic groups. The second was the household survey using interview schedules face-to-face for gathering the required information from sample of 123 households. The data collected from the two-step process provided community and individual level information for analysis. Gender roles were examined for access to agricultural extension/veterinary services, community services and finance and control over crop, livestock and off-farm incomes.

\section{RESULTS AND DISCUSSION}

\section{Gender roles on access to agricultural extension services}

The results supported the hypothesis that males have overwhelming access $(80 \%)$ to agricultural and veterinary services in all the selected ethnic groups (Table 1). In all ethnic groups, a small percentage of respondents reported that both men and women had access to these services. Tharu women had no access at all while only about one in six (18\%) Brahmin/Chbetri and Gurung women had access to extension services (Table 1). Both gender analysis and household survey indicated similar results.

Table 1. Access to agricultural extension and veterinary services by gender and ethnicity in the Chitwan district, Nepal. (Percent respondents responding)

\begin{tabular}{|c|c|c|c|c|c|c|c|c|c|c|c|c|}
\hline \multirow{3}{*}{ Access to: } & \multicolumn{12}{|c|}{ Gender role and ethnicity } \\
\hline & \multicolumn{3}{|c|}{ Brahmin/Chhetri } & \multicolumn{3}{|c|}{ Gurung } & \multicolumn{3}{|c|}{ Tharu } & \multicolumn{3}{|c|}{ Total } \\
\hline & $\mathbf{M}$ & $\mathrm{F}$ & B & $\mathbf{M}$ & F & B & $\mathbf{M}$ & $\mathbf{F}$ & B & $\mathbf{M}$ & F & B \\
\hline Agricultural extension ${ }^{a}$ & 71 & 18 & 11 & 73 & 17 & 10 & 93 & 0 & 7 & 79 & 12 & 9 \\
\hline Veterinary worker ${ }^{b}$ & 74 & 8 & 18 & 80 & 18 & 2 & 98 & 0 & 2 & 84 & 8 & 8 \\
\hline Veterinary hospital $^{\mathrm{c}}$ & 78 & 10 & 12 & 59 & 17 & 24 & 87 & 0 & 13 & 74 & 9 & 17 \\
\hline
\end{tabular}

${ }^{a}$ Brahmin/Chhetri ( $\left.n=38\right)$, Gurung $(n=41)$, Tharu $(n=40)$, Total $(n=119)$

${ }^{\mathrm{b}}$ Brahmin/Chhetri $(\mathrm{n}=39)$, Gurung $(\mathrm{n}=40)$, Tharu $(\mathrm{n}=40)$, Total $(\mathrm{n}=119)$

${ }^{\mathrm{c} B r a h m i n} /$ Chhetri $(\mathrm{n}=40)$, Gurung $(\mathrm{n}=41)$, Tharu $(\mathrm{n}=38)$, Total $(\mathrm{n}=119)$

$\mathrm{M}=$ Male; $\mathrm{F}=\mathrm{Female} ; \mathrm{B}=$ Both male and female

Source: Field survey, 1998 
Better access to extension services for males may have stemmed from the virtually non-existence of female extension workers and the reluctance of women in approaching male extension workers for receiving technical advice and services (Prah, 1997). This also reflects the male dominance in Nepalese society as well, where men enjoy privilege of access to activities outside the home, and have more free time than do women (Acharya, 1993; Bajracharya, 1994; Devkota, 1999). It is also likely that male extension workers are reluctant to approach women; and rural women in particular face cultural barriers that limit their confidence in interacting with male extension worker (Rahman, 2000).

\section{Gender roles on access to community services}

Access to three community service activities- participation in community meetings, skill development training and farming related study tour were examined (Table 2). Female members had restricted access to skill development training $(\mathrm{P}<0.001)$. In the Brahmin/Chhetri ethnic groups, only males had access to these activities (Table 2). The Gurungs, however, reported that in most cases women and men both participated in training opportunities.

More than two-thirds of the Gurung males had access to farm study tours. Tharu males also dominated access to community meetings and farm study tours, while about half of the respondents agreed that men and women had equal access to skill development training, with no Tharu women being able to attend a community meeting (Table 2). Both Brabmin/Chbetri and Tharu males had a strong domination to access in community meetings, skill development training, and farming study tour. In contrast, gender participation in community meetings, marketing of crops and livestock were approximately equal among the Gurungs as assessed from community information through gender analysis approach (Table 3).

Table 2. Gender participation on access to community activities and training in Chitwan district, Nepal. (Percent respondents responding)

\begin{tabular}{|c|c|c|c|c|c|c|c|c|c|c|c|c|c|}
\hline \multirow{3}{*}{ Access to: } & \multicolumn{13}{|c|}{ Gender role and ethnicity } \\
\hline & \multicolumn{3}{|c|}{ Brahmin/Chhetri } & \multicolumn{3}{|c|}{ Gurung } & \multicolumn{3}{|c|}{ Tharu } & \multicolumn{4}{|c|}{ Total } \\
\hline & $\mathbf{M}$ & $\mathrm{F}$ & B & $\mathbf{M}$ & $\mathrm{F}$ & B & $\mathbf{M}$ & $\mathrm{F}$ & B & $\mathbf{M}$ & $\mathrm{F}$ & B & Chisquare \\
\hline Community meetings ${ }^{a}$ & 68 & 10 & 22 & 38 & 38 & 24 & 68 & 0 & 32 & 58 & 16 & 26 & $24.6(4) * *$ \\
\hline Skill development training $\mathrm{b}$ & 58 & 12 & 30 & 10 & 73 & 17 & 32 & 13 & 55 & 35 & 31 & 34 & $43.1(4) * *$ \\
\hline Farming study tour ${ }^{c}$ & 58 & 14 & 28 & 67 & 27 & 6 & 85 & 11 & 4 & 69 & 17 & 14 & NS \\
\hline
\end{tabular}

Source: Field survey, 1998

** refers to statistical significance at $1 \%$ level of probability based on the chi-square test of independence of participation by ethnicity

${ }^{a}$ Brahmin/Chhetri $(n=40)$, Gurung $(n=42)$, Tharu $(n=40)$, Total $(n=122)$, 'Brahmin/Chhetri $(n=40)$, Gurung $(n=30)$, Tharu ( $\left.n=31\right)$, Total $(n=101)$

'Brahmin/Chhetri $(n=36)$, Gurung $(n=30)$, Tharu ( $n=27)$, Total $(n=93), M=$ Male; $F=$ Female; $B=$ Both male and female, NS= Non significant.

Table 3. Access to resource and other farm activities by gender and ethnicity in Chitwan district, Nepal. (Gender Analysis Approach)

\begin{tabular}{|c|c|c|c|c|c|c|}
\hline \multirow{3}{*}{ Access to: } & \multicolumn{6}{|c|}{ Ethnicity and gender role (Gender Analysis) } \\
\hline & \multicolumn{2}{|c|}{ Brahmin/Chhetri } & \multicolumn{2}{|c|}{ Gurung } & \multicolumn{2}{|c|}{ Tharu } \\
\hline & $\mathbf{M}$ & $\mathrm{F}$ & $\mathbf{M}$ & $\mathrm{F}$ & $\mathbf{M}$ & $\mathrm{F}$ \\
\hline Land & $\checkmark \checkmark$ & & $\sqrt{ }$ & & $\checkmark \sqrt{ }$ & $\checkmark$ \\
\hline Agricultural extension service & $\checkmark \checkmark$ & & $\sqrt{ }$ & & $\checkmark \checkmark$ & $\checkmark$ \\
\hline Participation on agricultural training & $\checkmark \checkmark$ & & $\sqrt{ }$ & & $\checkmark \checkmark$ & \\
\hline Skilled development training & $\checkmark \checkmark$ & & $\sqrt{ }$ & & $\checkmark \checkmark$ & $\checkmark$ \\
\hline On-farm work & $\checkmark \checkmark$ & & $\checkmark \checkmark$ & & $\checkmark \checkmark$ & \\
\hline Off-farm employment opportunity & $\checkmark \checkmark$ & & $\checkmark \checkmark$ & & $\checkmark \checkmark$ & \\
\hline Participation in community meeting & $\checkmark \checkmark$ & & $\checkmark \checkmark$ & $\sqrt{ }$ & $\checkmark \checkmark$ & \\
\hline Marketing of cereal crops & $\checkmark \checkmark$ & & $\checkmark \checkmark$ & $\checkmark \checkmark$ & $\checkmark \checkmark$ & \\
\hline Marketing of cash crop & $\checkmark \checkmark$ & & $\checkmark \checkmark$ & $\checkmark \checkmark$ & $\checkmark \checkmark$ & \\
\hline Marketing of large animals & $\checkmark \checkmark$ & & $\checkmark \checkmark$ & $\sqrt{ }$ & $\checkmark \checkmark$ & \\
\hline Marketing of small animals & $\checkmark \checkmark$ & $\sqrt{ }$ & $\checkmark$ & $\sqrt{ }$ & $\checkmark$ & $\sqrt{ }$ \\
\hline Banking facility & & & & $\sqrt{ }$ & $\checkmark \checkmark$ & \\
\hline Private money lenders & $\sqrt{ }$ & & & $\sqrt{ }$ & $\checkmark \checkmark$ & \\
\hline Jewelry & $\checkmark \checkmark$ & & & $\checkmark \checkmark$ & $\checkmark \checkmark$ & \\
\hline Savings & $\sqrt{ }$ & & & $\checkmark \checkmark$ & $\checkmark \checkmark$ & $\checkmark$ \\
\hline
\end{tabular}

Source: Field work, gender analysis, 1998.

$\mathrm{M}=$ Male, $\mathrm{F}=$ Female $(\boldsymbol{V} \mathfrak{})$ denotes strong and $(\boldsymbol{V})$ weak participation for access to household resources and other farm activities 
Equal participation of Gurung women in the community meetings could be due to the fact that many males absent from home because of their employment in the military services. In relation to access to study tours, however, involving travel away from home, therefore, male's domination was found in all ethnic groups (Table 3). Traditionally, women are not supposed to leave the village boundaries, some of whom are even restricted to go beyond the boundaries of their own houses and agricultural land (Acharya, 1993; Bajracharya, 1994; Devkota, 1999). Women's access to resources not only determined by their cultural norms and social values but also by their relationship to men as daughters, wives or sisters (Bajracharya, 1994).

\section{Gender roles on access to financial services}

Access to financial services was also dominated by men (Table 4). Women's access to financial activities was very poor among the Tharu community. Males that of Brahmin/Chbetri communities had easy access to financial institutions, Gurung women, on the other hand, did not have good access to formal financial institutions such as banks, but had good access to private money lenders ( $\mathrm{P}<0.001)$, and greater access to savings than men. Similar information was also obtained from the community response in gender analysis exercise, that access of Gurung women to financial activities such as savings and private moneylenders was higher. These resources were, however, dominated by males in the Brahmin/Chbetri and Tharu ethnic communities (Table 4).

Table 4. Access to financial activities by gender and ethnicity in the Chitwan district, Nepal. (Percent respondents responding)

\begin{tabular}{|c|c|c|c|c|c|c|c|c|c|c|c|c|c|}
\hline \multirow{3}{*}{ Access to: } & \multicolumn{13}{|c|}{ Gender role and ethnicity } \\
\hline & \multicolumn{3}{|c|}{ Brahmin/Chhetri } & \multicolumn{3}{|c|}{ Gurung } & \multicolumn{3}{|c|}{ Tharu } & \multicolumn{4}{|c|}{ Total } \\
\hline & M & $\mathrm{F}$ & B & $\mathbf{M}$ & $\mathrm{F}$ & B & M & $\mathrm{F}$ & B & $\mathbf{M}$ & $\mathrm{F}$ & B & Chisquare \\
\hline Banking facility ${ }^{a}$ & 65 & 23 & 12 & 61 & 22 & 17 & 97 & 3 & 0 & 75 & 15 & 10 & NS \\
\hline Private money lender ${ }^{\mathrm{b}}$ & 57 & 14 & 29 & 45 & 41 & 14 & 95 & 3 & 2 & 66 & 20 & 14 & $32.7(4)^{* *}$ \\
\hline Savings ${ }^{c}$ & 88 & 4 & 8 & 26 & 61 & 13 & 94 & 3 & 3 & 65 & 27 & 8 & NS \\
\hline
\end{tabular}

Source: Field survey, 1998

** refers to statistical significance at $1 \%$ level of probability based on the chi-square test of independence of participation by ethnicity ${ }^{a}$ Brahmin/Chhetri ( $\left.n=17\right)$, Gurung ( $\left.n=36\right)$, Tharu ( $\left.n=32\right)$, Total $(n=85),{ }^{b}$ Brahmin/Chhetri $(n=35)$, Gurung $(n=42)$, Tharu ( $\left.=40\right)$, Total ( $\left.n=117\right)$ ${ }^{\mathrm{c} B r a h m i n} /$ Chhetri $(\mathrm{n}=25)$, Gurung $(\mathrm{n}=39)$, Tharu $(\mathrm{n}=33)$, Total $(\mathrm{n}=97), \mathrm{M}=$ Male; F=Female; $\mathrm{B}=$ Both male and female, NS= Non significant.

The absence of males seems to have given Gurung women the opportunity to take overall access to household financial activities compared to the Brahmin/Chhetri and Tharu women. In general, women were largely illiterate in all the ethnic groups, and thus were not involved in financial activities (especially for banking activities), which required knowledge/ skills (Bajracharya, 1994). This is why males had better access to financial activities than females in the rural society (Table 4).

\section{Gender roles on control of crop income}

Variation in the control of crop income was significant $(\mathrm{P}<0.001)$ among the ethnic groups. More than two-thirds of Brabmin/Chhetri respondents reported that males had control over crop income which was just reverse in Gurung ethnic group. Interestingly, more than two-thirds of Tharus had joint control over the crop income (Table 5).

Table 5. Control over crop production income by gender and ethnicity in Chitwan district, Nepal. (Percent respondents responding)

\begin{tabular}{|c|c|c|c|c|c|c|c|c|c|c|c|c|c|}
\hline \multirow{3}{*}{ Access to: } & \multicolumn{13}{|c|}{ Gender role and ethnicity } \\
\hline & \multicolumn{3}{|c|}{ Brahmin/Chhetri } & \multicolumn{3}{|c|}{ Gurung } & \multicolumn{3}{|c|}{ Tharu } & \multicolumn{4}{|c|}{ Total } \\
\hline & M & $\mathrm{F}$ & B & $\mathbf{M}$ & $\mathrm{F}$ & B & $\mathbf{M}$ & $\mathrm{F}$ & B & M & $\mathrm{F}$ & B & Chisquare \\
\hline Cereal crop income a & 76 & 13 & 11 & 19 & 74 & 7 & 24 & 5 & 71 & 41 & 27 & 32 & $36.8(4)^{* *}$ \\
\hline Cash crop income ${ }^{b}$ & 76 & 11 & 13 & 18 & 75 & 7 & 21 & 11 & 68 & 40 & 29 & 31 & $72.1(4)^{* *}$ \\
\hline
\end{tabular}

Source: Field survey, 1998

** refers to statistical significance at $1 \%$ level of probability based on the chi-square test of independence of participation by ethnicity ${ }^{a}$ Brahmin/Chhetri ( $\left.\mathrm{n}=37\right)$, Gurung $(\mathrm{n}=27)$, Tharu $(\mathrm{n}=38)$, Total $(\mathrm{n}=102)$, 'brahmin/Chhetri $(\mathrm{n}=37)$, Gurung $(\mathrm{n}=28)$, Tharu $(\mathrm{n}=37)$, Total $(\mathrm{n}=102)$ $\mathrm{M}=$ Male; $\mathrm{F}=$ Female; $\mathrm{B}=$ Both male and female 
Information of gender analysis exercise showed that male had a strong control over, all the household resources in the Brahmin/Chhetri and Tharu communities, while visible joint control of Gurung men and women was found for the marketing of crops (Table 6).

Table 6. Control over household resources and farm activities by gender and ethnicity in Chitwan district, Nepal. (Gender Analysis Approach)

\begin{tabular}{|lccccc|}
\hline & \multicolumn{3}{c|}{ Ethnicity and gender role (Gender Analysis) } \\
\cline { 2 - 5 } Access to: & Brahmin/Chhetri & Gurung & \multicolumn{2}{c|}{ Tharu } \\
\cline { 2 - 5 } & M & F & F & M & $\checkmark \checkmark$ \\
Land & $\checkmark \checkmark$ & & $\checkmark \checkmark$ & $\checkmark \checkmark$ & $\checkmark \checkmark$ \\
Agricultural extension service & $\checkmark \checkmark$ & $\checkmark \checkmark$ & $\checkmark \checkmark$ & $\checkmark \checkmark$ \\
Participation on agricultural training & $\checkmark \checkmark$ & $\checkmark \checkmark$ & $\checkmark \checkmark$ & $\checkmark \checkmark$ \\
Skilled development training & $\checkmark \checkmark$ & & $\checkmark \checkmark$ & & $\checkmark \checkmark$ \\
On-farm work & $\checkmark \checkmark$ & & $\checkmark \checkmark$ & $\checkmark$ & $\checkmark \checkmark$ \\
Off-farm employment opportunity & $\checkmark \checkmark$ & & $\checkmark \checkmark$ & & $\checkmark \checkmark$ \\
Participation in community meeting & $\checkmark \checkmark$ & & $\checkmark \checkmark$ & $\checkmark \checkmark$ & $\checkmark \checkmark$ \\
Marketing of cereal crops & $\checkmark \checkmark$ & & $\checkmark \checkmark$ & $\checkmark \checkmark$ & $\checkmark \checkmark$ \\
Marketing of cash crop & $\checkmark \checkmark$ & $\checkmark$ & $\checkmark \checkmark$ & $\checkmark \checkmark$ & $\checkmark \checkmark$ \\
Marketing of large animals & $\checkmark \checkmark$ & & $\checkmark \checkmark$ & $\checkmark \checkmark$ & $\checkmark \checkmark$ \\
Marketing of small animals & $\checkmark \checkmark$ & $\checkmark$ & $\checkmark \checkmark$ & $\checkmark$ \\
Banking facility & $\checkmark \checkmark$ & & $\checkmark \checkmark$ & $\checkmark \checkmark$ \\
Private money lenders & $\checkmark \checkmark$ & & $\checkmark \checkmark$ & $\checkmark \checkmark$ \\
Jewelry & $\checkmark \checkmark$ & & $\checkmark \checkmark$ & $\checkmark \checkmark$ \\
Savings & $\checkmark \checkmark$ & & $\checkmark \checkmark$ & $\checkmark \checkmark$ \\
\hline
\end{tabular}

Source: Field survey, 1998

$\mathrm{M}=$ Male, $\mathrm{F}=$ Female $(\boldsymbol{V})$ denotes strong and $\boldsymbol{\checkmark}$ ) weak participation for control over household resources and other farm activities

A higher degree of control of crop income by Gurung females most likely stems from the absence of males, from the household for large parts of the year. Less control by women alone in the Brahmin/Chbetri and Tharu households reflects the social norm that men usually deal with the finance (Bajracharya, 1994; Acharya, 1993).

\section{Gender roles on control of livestock income}

Control over the livestock income, mainly from the sale of large and small ruminants, varied significantly $(\mathrm{P}<0.001)$ among ethnic groups (Table 7). Gurung women controlled livestock income overwhelmingly, whereas this was controlled by males in the Brahmin/Chbetri households. The Tharu households indicated joint control over the income earned from the sale of large animals, while women had more control over income from small animals (Table 6). Gender analysis exercise in relation to control over livestock income showed joint control of both male and female in Gurung, while male domination was strong in Brahmin/Chhetri and Tharu. The survey revealed that Gurung women control livestock income, while in the Brahmin/Chbetri households control rested with men. The Tharu households indicated joint control over the income earned from the sale of large animals, while women had more control over income from small animals (Table 7).

Table 7. Control over livestock income by gender and ethnicity in the Chitwan district, Nepal (Percent respondents responding)

\begin{tabular}{|c|c|c|c|c|c|c|c|c|c|c|c|c|c|}
\hline \multirow{3}{*}{ Control over: } & \multicolumn{13}{|c|}{ Gender role and ethnicity } \\
\hline & \multicolumn{3}{|c|}{ Brahmin/Chhetri } & \multicolumn{3}{|c|}{ Gurung } & \multicolumn{3}{|c|}{ Tharu } & \multicolumn{4}{|c|}{ Total } \\
\hline & M & $\mathrm{F}$ & B & M & $\mathrm{F}$ & B & $\mathbf{M}$ & $\mathrm{F}$ & B & $\mathbf{M}$ & $\mathrm{F}$ & B & Chisquare \\
\hline Income of large animals a & 72 & 13 & 15 & 30 & 61 & 9 & 31 & 15 & 54 & 47 & 30 & 23 & $39.0(4) * *$ \\
\hline Income of small animals $b$ & 70 & 9 & 11 & 22 & 74 & 4 & 15 & 48 & 37 & 36 & 46 & 18 & NS \\
\hline
\end{tabular}

Source: Field survey, 1998

** refers to statistical significance at $1 \%$ level of probability based on the chi-square test of independence of participation by ethnicity ${ }^{a}$ Brahmin/Chhetri $(\mathrm{n}=39)$, Gurung $(\mathrm{n}=33)$, Tharu $(\mathrm{n}=26)$, Total $(\mathrm{n}=98)$, ${ }^{\mathrm{b}}$ Brahmin/Chhetri $(\mathrm{n}=27)$, Gurung $(\mathrm{n}=23)$, Tharu $(\mathrm{n}=27)$, Total $(\mathrm{n}=77)$ $\mathrm{M}=$ Male; $\mathrm{F}=$ Female; $\mathrm{B}=$ Both male and female, $\mathrm{NS}=$ Non significant 


\section{Gender roles on control over off-farm income}

The Brabmin/Chbetri males dominated in the control of off-farm income which significantly varied among the ethnic groups $(\mathrm{P}<0.001)$, however, both men and women in all ethnic group jointly controlled the money received from pensions and remittances (Table 8). Majority (55\%) of the Tharu respondents reported joint control of off-farm income. None from this group received income from pensions or remittances. Gurung females, on the other hand, had greater control than males over income from both off-farm employment and pensions/remittances (Table 8).

The Brabmin/Chbetri males dominated in the control of off-farm income, which seems to be realistic because of their greater freedom to travel and earn it. However both men and women controlled money received from pensions and remittances. Except in Gurung community women from Brahmin/Chhetri, and Tharu community were deprived of access to cash and thus would depend on their male counterparts to meet their household expenses. Both household survey and gender analysis revealed consistency in results for most of the variables studied included in this research. The findings of the study demonstrates that male domination was widely prevalent in all the ethnic groups with respect to access to and control over household resources of the three ethnic groups examined, the Gurung women were better off compared to Brahmin/Chhetri and the Tharu women. However, this was largely associated with male absence for prolonged period of time.

Table 8. Control over off-farm income by gender and ethnicity in Chitwan district, Nepal. (Percent respondents responding)

\begin{tabular}{|c|c|c|c|c|c|c|c|c|c|c|c|c|c|}
\hline \multirow{3}{*}{ Control over: } & \multicolumn{13}{|c|}{ Gender role and ethnicity } \\
\hline & \multicolumn{3}{|c|}{ Brahmin/Chhetri } & \multicolumn{3}{|c|}{ Gurung } & \multicolumn{3}{|c|}{ Tharu } & \multicolumn{4}{|c|}{ Total } \\
\hline & $\mathbf{M}$ & $F$ & B & $\mathbf{M}$ & $F$ & B & $\mathbf{M}$ & $F$ & B & $\mathbf{M}$ & $F$ & B & Chisquare \\
\hline Off-farm income ${ }^{a}$ & 74 & 6 & 20 & 24 & 60 & 16 & 30 & 15 & 55 & 43 & 29 & 28 & $44(4) * *$ \\
\hline Income of pension and remittances $b$ & 17 & 33 & 50 & 27 & 64 & 9 & 0 & 0 & 0 & 24 & 53 & 23 & NS \\
\hline
\end{tabular}

Source: Field survey, 1998

** refers to statistical significance at $1 \%$ level of probability based on the chi-square test of independence of participation by ethnicity

${ }^{a}$ Brahmin/Chhetri $(n=35)$, Gurung $(n=38)$, Tharu $(n=27)$, Total $(n=100)$, brahmin/Chhetri $(n=6)$, Gurung $(n=11)$, Tharu ( $\left.=0\right)$, Total $(n=17)$

$\mathrm{M}=$ Male $\mathrm{F}=$ Female $\mathrm{B}=$ Both male and female, $\mathrm{NS}=$ Non significant.

\section{CONCLUSIONS}

There are clear barriers in women's access to agricultural production services in rural Nepal, such as those provided by extension officers, and they typically have limited control over certain household resources, such as income. Lack of access to, and control over, resources is likely to result in a gender imbalance in decision-making and poor participation of women in developmental activities. It also means that women are likely to be deprived in relation to the access of information related to agricultural innovations and technological development.

\section{REFERENCES CITED}

Acharya, M. 1994. Statistical profile of Nepalese women: An update in the policy context. Institute of Integrated Development Studies, Kthmandu, Nepal.

Acharya, M. 1993. The household economy and women's work in Nepal. In: S. Raju, and D. Bagchi (eds.) Women and Work in South-Asia: The Regional Patterns and Perspectives. Routledge, London.

Anonymous 2002. Gender assessment study of the agricultural sector. Center for Policy Studies, Kalimati, Kathmandu, Nepal.

Bajracharya, B. 1994. Gender issues in Nepali agriculture: A review. Winrock Research Report Series, No. 25. Kathmandu: Ministry of Agriculture/ Winrock International.

Barrett, H. and A. Browne. 1993. The impact of labour saving devices on the lives of rural African women. In: J. H. Momsen and V. Kinnaird (eds.) Different Places, Different Voices: Gender and Development in Africa, Asia and Latin America. Routledge, London.

Buvinic, M. and R. Mehra. 1990. Women and agricultural development. In: C. K. Eicher and J. M. Staatz (eds.) Agricultural Development in the Third World. Baltimore: The Johns Hopkins University Press. 
CBS 1997. Statistical year book of Nepal 1997. Central Bureau of Statistics, National Planning Commission Secretariat, Kathmandu, Nepal.

Devkota, D. 1999. Household decision making in rural Nepal: A study of the effects of gender roles and ethnicity. Master thesis (Unpublished). Massey University, New Zealand.

Hans, R. 1999. Society in India. SBD Publishers' Distributors, New Delhi, India.

Hutchinson, J. and A. D. Smith. 1996. Ethnicity. Oxford University Press, New York.

Jazairy, I., M. Alamgir, and T. Panuccio. 1992. The state of world rural poverty. IT Publication, London.

Kwinjch, G. and T. Mgugu. 1996. Women's access to and control over resources within the family. A Gender and Development Newsletter for Southern Africa, Issue No. 5.

Moser, C.O.N. 1993. Gender planning and development: Theory, practice and training. Routledge, London.

Okojie, C.E.E. 1996. Women in the rural economy in Nigeria. In: P. Ghorayshi and C. Belanger (eds.) Women, Work and Gender Relations in Developing Countries: A Global Perspective. Greenwood Press, London.

Overholt, C, K. Cloud, M. Anderson, and J. Sustin. 1991. Gender analysis framework. In: A. Rao et al. (eds.) Gender Analysis in Development Planning: A Casebook. Kumarian Press, West Hartford, USA.

Paul, R. B. 1996. Ethnic group and ethnic identity formation. In: J. Hutchinson and A.D. Smith (eds.) Ethnicity. Oxford University Press, New York.

Prah, M. 1997. Constraints limiting the access of women to production inputs in Ghana. In: A.B. Steven (ed.) Women, Agricultural Intensification, and Household Food Security. Sasakawa Africa Association.

Rahman, S. 2000. Women's employment in Bangladesh agriculture: Composition, determinants and scope. J. Rural Studies 16:497-507.

Shrestha, S. L. 1994. Gender sensitive planning what, why and how in Nepal : Women Awareness Center Nepal (WACN), Kathmandu, Nepal.

Shtrii Shakti. 1995. Women development democracy: A study of the socio-economic changes in the status of women in Nepal. Kathmandu, Nepal.

Subedi, P. 1997. Nepali women rising. Sahayogi Press, Kathmandu, Nepal.

Thomas-Slayter, B. and D. Rocheleau. 1995. Gender environment and development in Kenya: A grassroots perspective. London: LYNEE RIENNER Publisher.

Wickramasinghe, A. 1993. Women's role in rural Sri Lanka. In: J.H. Momsen and V. Kinnaird (eds.) Different Places, Different Voices: Gender and Development in Africa, Asia and Latin America. Routledge, London. 